\title{
FUNDAMENTALS OF LONG-TERM TRAINING SYSTEMS IN MIND SPORTS
}

review paper

( ) University School of Physical Education in Wroclaw

DOI: https://doi.org/10.5114/hm.2020.91341

\section{NINA DOLBYSHEVA}

Prydniprovsk State Academy of Physical Culture and Sports, Dnipro, Ukraine

\begin{abstract}
On the basis of an analytical review of scientific and methodological literature, generalization of documentary materials, and a systematic approach, the general and particular laws of the system and the 'subsystem' of sports training in mind sports are revealed. Given the specificity of the competition and the training process in athletes of mind sports, associated with abstract-gaming activities and lack of physical activity, the entire training system is considered from general pedagogical positions as a process of applied-specialized training and education. The basis of the training system in mind sports is competences (cognitive, creative, communicative, social), formed through the implementation of didactic, specific principles of sports training and specific principles of organizing educational and cognitive activity and the 'subsystem' of sports training, within the framework of competitions and sports training. The specific principles of educational and cognitive activity include the strength of learning, emotional and problematic learning, the connection of theory with practice, validity, cyclical development, modelling, computerization, and self-management, competitive activity in the context of specific features in the organization of full-time and distance competitions, the system of conducting and determining sports result. Sports training is aimed at the development of sports form through intellectual, specially practical, psychological, and physical training, which acts as an additional one. The whole 'system' and its 'subsystem' are associated with the stages of long-term preparation and systemic factors that affect the entire system.
\end{abstract}

Key words: system, competence, principles, stages, factors, mind sports athletes

\section{Introduction}

Scientific approaches to sport types categorization point to the group of mind sports which include chess, checkers, the Go game, sports bridge, sports poker, etc. These are competitive activities connected with abstract games and lack of physical activity [1-4]. The preparation system in these sports consists in a longterm, year-round, special, and organized process carried out on the basis of regular educational trainings and competitions.

The nature of a general training system of athletes in dynamic sports at the theoretical and methodical levels has been described, among others, by scientific works of Platonov, Maveev, Deminsky, Keller, Nabatnikova, Sahnovskiy, or Ozolin. The scientific and methodical literature analysis revealed the absence of theoretical fundamentals and general regularities in the mind sports preparation system. However, certain aspects of athlete training in particular sports types have scientific justification and are introduced into sports practice [5-14].

\section{The basis of the training system in mind sports}

The core objective of athletes sports training system in mind sports is the achievement of high sports results at competitions of national, continental, regional, and international scale, which are reached owing to abstract and logical thinking, implementation of mental and intellectual abilities.

The efficiency of mind sports athletes' competitive activity depends on sports preparation within major

Correspondence address: Nina Dolbysheva, Department of Theory and Methodology of Sport Training,

Faculty of Physical Culture and Sports, Prydniprovsk State Academy of Physical Culture and Sports,

Naberezhnaja Pobedy Str. 10, Dnipro - 94, Ukraine, 49094, e-mail: dolbysheva-nina@rambler.ru

Received: June 24, 2019

Accepted for publication: October 3, 2019

Citation: Dolbysheva N. Fundamentals of long-term training systems in mind sports. Hum Mov. 2020;21(3):1-20; doi: https://doi.org/10.5114/hm.2020.91341. 


\section{HUMAN MOVEMENT}

N. Dolbysheva, Training in mind sports

objectives, covering quite a wide range: instilling a steady interest in sports activities; gaining special knowledge, competences, and skills on technical aspects, tactics, and strategy of a game crucial for successful performance at competitions; mastering core regularities of strong will and physical training; cultivation of high moral and ethical qualities; acquisition of the basic principles of game aesthetics and their practical application.

Along with the above stated, one of the main tasks is the formation of certain competences aimed at gaining special (basic and fundamental) knowledge, intellectual and procedural skills, formation of potential readiness to solve specific game problems and to be capable of performing scientific search, i.e.:

- cognitive competence, characterized by the scope of special knowledge and skills necessary for successful use of specific means and methods of preparation, mastering technical basics, tactics of a game, and modern information technologies;

- practical competence, connected with the ability to implement the basic principles of game ethics (pursuing ideally precise game, search for the proper and at the same time deep, extraordinary, and externally 'beautiful' game solutions and their application in the practical game), to acquire and implement an individual game style in competitive practice;

- creative competence, which features the level of development of spatial and logical thinking, imagination, power to demonstrate game initiative, capability to solve creative problems and show a creative approach in game activity;

- communicative competence, characterized by the volume of knowledge related to the use of 'linguistic' communication, aptness to alter the social circle and ways of interacting with athletes, coaches, judges, fans, the press, etc., ability to apply teamwork skills through setting and maintaining the necessary contacts during the training and competitive activities, as well as skills for analysing communicative situations represented in verbal and visual forms;

- social competence, which implies the level of public consciousness and national dignity, implementation of professional team interaction skills, creation of comfortable and friendly environment, capability to influence the opponent and possess the language of gestures.

In accordance with the method of scientific cognition - analogy - the formation of mind sports athletes' special competences is ensured through implementation of the system and the 'subsystem' of sports training, directly via application of principles, participation in competitions and sports training based on the essential sports formation laws at different stages of long-term preparation along with influencing system factors (Figure 1).

An effective training system is possible in terms of sports training principles implementation reflecting basic regularities of training process creation, training loads planning, and the development of ath-

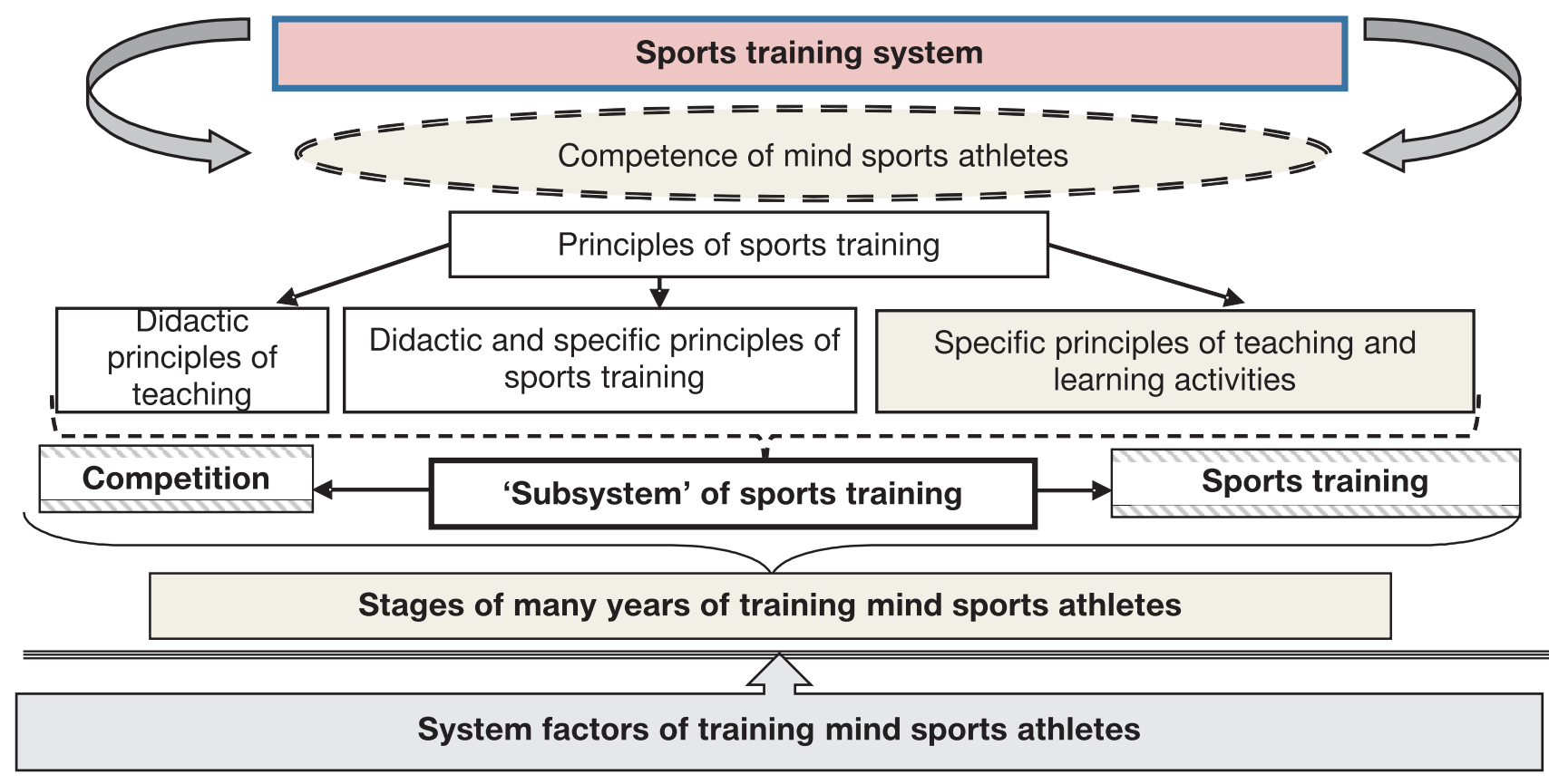

Figure 1. Components of the training system for athletes in mind sports [15] 
Table 1. Specific principles of the educational and cognitive activities organization implemented in the system of mind sports training

Principle

Knowledge mastering substantiality

Emotional education

Problematic learning

Problematic learning

Theory-practice link

Validity

Cyclical development

Direction

Conscious and deep formation of basic knowledge in the form of facts, concepts, ideas, laws, and rules inherent in mind sports, and of fundamental knowledge on the foundations of sports training aspects and their implementation, as well as features of competitive activity

Creation of certain emotional states and feelings stimulating successful gaining of special knowledge, formation of interest in classes, and development of internal motivations

Formation of creative abilities through the development of thinking and scientific cognition

Combination of mental activity with practice, connection of theoretical and practical training

Formation of fundamental, accurate, evidentiary, and complete knowledge through their aware learning and use in sports practice

Cyclical process of using theoretical and practical tasks of the game in accordance with the cyclicality coherence of mental and intellectual abilities

Modelling

Improvement of fundamental knowledge, practical skills of the game, and the implementation of mental and intellectual abilities on account of game situations simulation

Computerization

Utilization of computer technologies providing an individual and differentiated approach to the training process and cognitive interests development

Self-management

Creation of an individual style of sports activities

letes' shape and fitness. Educational and methodical, popular and scientific literature outlines the evidencebased didactic principles of training $[3,16]$, specific principles of sports training $[3,4,16-20]$, and special didactic principles which were adapted to sports practice by Gaverdovskiy [21].

We focus on the specific principles of the educational and cognitive activity organization since the entire system of training mind sports athletes is associated with cognitive activity affecting the training process efficiency and the competitive activity outcome (Table 1). This is explained by the fact that the training process in mind sports is connected, on the one hand, with the athlete's educational training activities aimed at knowledge formation, mental and intellectual abilities development, and, on the other hand, with cognitive activities targeting at encouragement of aspiration to learn new things through the use of various methods and means of cognition. Therefore, while these principles are implemented in the training process, with the consideration of their peculiarities, sports training acquires a new system-quality level.

The outlined specific competences of mind sports athletes formed in the process of long-term preparation on the basis of the core laws and implementation of specific principles of educational and cognitive activity arrangement confirm the theory of Matveev with regard to the system of athletes training from general pedagogical positions as an application of a specialized process of training and education [16, 18].

\section{Competition as a component of the 'subsystem' process of mind sports training}

The process of mind sports athlete training for high sporting achievements has a complex nature and is implemented through a 'subsystem' which covers competition and sports training (Figure 1).

Platonov [4, 19, 22], Platonov and Sahnovskiy [23], Matveev [16, 18, 24], and others state that competitions are a basis of sport existence and development for the international community and for a person's socialization. In the course of competitions, the level of an athletes' readiness to achieve high sports results or victories is verified in non-antagonistic rivalry regulated by special rules and conditions. Competitions are a peculiar model of human relations existing in sport (fight, victories, defeats, mutual aid), aimed at satisfying creative and prestigious purposes; on the other hand, they are means of an athlete's sports skills training and improvement, as well as of control over their preparation level. Competitions are aimed at achieving an objective and subjective target result. The objective result is considered an athlete's achievement and their world rating level whereas the subjective one 


\section{HUMAN MOVEMENT}

N. Dolbysheva, Training in mind sports

is a priority in utilization of efficient means and methods of an athlete's training, material, technical, financial, methodological, and medical support, as well as the coaches' preparation level.

The arrangement and holding of competitions in mind sports and achievement of results are based on the implementation of the code (rules) of chess, checkers, Go, bridge, sports poker [25-29], Code of Sports Ethics [30], and anti-doping regulations [31-34], which are revised and complemented with the consideration of current global development trends of these sports.
Competitions among mind sports athletes are conducted on amateur and professional levels.

The amateur level in the territory of Ukraine, which targets at a certain level of sports preparation achievement and entry into the world ranking, is stipulated by participation of mind sports athletes of various age categories in national, continental, regional, and international competitions (Table 2) with a subsequent nomination of sports categories and grades in accordance with the Ukrainian national rules of competitions.

Table 2. The amateur level of competitions in mind sports

\begin{tabular}{|c|c|c|c|c|}
\hline \multirow{2}{*}{ Age group } & \multicolumn{2}{|c|}{ Athletes' age } & \multirow{2}{*}{$\begin{array}{l}\text { Assignment of sports ranks } \\
\text { and titles }\end{array}$} & \multirow{2}{*}{$\begin{array}{l}\text { Levels of sporting } \\
\text { achievements }\end{array}$} \\
\hline & National rules & International code & & \\
\hline \multicolumn{3}{|l|}{ Chess } & \multirow{19}{*}{$\begin{array}{c}\text { Taking into account } \\
\text { the place in national } \\
\text { and international level } \\
\text { competitions or compliance } \\
\text { with the standards } \\
\text { for achieving individual } \\
\text { national and world rankings }\end{array}$} & \multirow{19}{*}{$\begin{array}{l}\text { Mass youth and adult sports } \\
\text { categories, Candidate Master } \\
\text { of Sports of Ukraine, } \\
\text { Master of Sports of Ukraine, } \\
\text { Master of Sports of Ukraine } \\
\text { of international class* }\end{array}$} \\
\hline Children & - & $\leq 10$ & & \\
\hline $\begin{array}{l}\text { Children- } \\
\text { cadets }\end{array}$ & $6-10$ & $11-17$ & & \\
\hline Juniors & $11-17$ & $18-20$ & & \\
\hline Adults & $\geq 18$ & $\geq 21$ & & \\
\hline \multicolumn{3}{|l|}{ Checkers } & & \\
\hline Young hopes & - & $\leq 8$ & & \\
\hline Hope & $\leq 10$ & $9-10$ & & \\
\hline Junior cadets & $11-13$ & $11-13$ & & \\
\hline Cadets & $14-16$ & $14-16$ & & \\
\hline Juniors & $17-19$ & $17-19$ & & \\
\hline Youth & $20-26$ & $20-26$ & & \\
\hline Adults & $\geq 27$ & $\geq 27$ & & \\
\hline \multicolumn{3}{|l|}{ Go game } & & \\
\hline Children & $\leq 12$ & - & & \\
\hline Cadets & $13-16$ & $\leq 12$ & & \\
\hline Juniors & $17-20$ & $13-18$ & & \\
\hline Youth & $21-29$ & $19-23$ & & \\
\hline Adults & $\geq 30$ & $\geq 24$ & & \\
\hline \multicolumn{3}{|l|}{ Bridge } & \multirow{5}{*}{$\begin{array}{c}\text { Taking into account the place } \\
\text { in national and international } \\
\text { level competitions }\end{array}$} & \multirow{5}{*}{$\begin{array}{c}\text { Mass adult sports categories, } \\
\text { Candidate Master of Sports } \\
\text { of Ukraine, Master of Sports } \\
\text { of Ukraine, Master of Sports } \\
\text { of Ukraine of international class }\end{array}$} \\
\hline Children & - & $\leq 15$ & & \\
\hline Juniors & - & $16-18$ & & \\
\hline Youth & - & 19-25 & & \\
\hline Adults & $\geq 18$ & $\geq 26$ & & \\
\hline
\end{tabular}

* In chess and checkers, at the level of 'Master of Sports of Ukraine of international class,' the rank of 'Grandmaster of Ukraine' is granted 
Table 3. International titles in mind sports [25, 26, 35]

\begin{tabular}{lll}
\hline Game & Men's international titles & Women's international titles* $^{*}$ \\
\hline \multirow{3}{*}{ Chess } & FIDE Master & Woman FIDE Master \\
& International Master & Woman International Master \\
& Grandmaster & Woman Grandmaster \\
\hline \multirow{3}{*}{ Checkers } & FMJD Master & Woman FMJD Master \\
& International Master & Woman International Master \\
& International Grandmaster & Woman International Grandmaster \\
\hline \multirow{3}{*}{ Bridge } & World Grand Master & World Grand Master \\
& World Life Master & World Life Master \\
& World International Master & World International Master \\
& World Master & World Master
\end{tabular}

* In chess and checkers, women are granted men's international ranks in cases of a successful game in a men's tournament. The first international rank of 'Grandmaster' was granted in 1978 to the Georgian chess player Nona Terentyevna Gaprindashvili.

The professional level is associated with the international rank achievement at the level of an international sports federation, which is granted by a decision of the qualification committee in the case of scoring a certain level of rating points and participation in competitions with a prize fund (Table 3).

Mind sports competitions are also held among physically disabled people (with visual or hearing impairment, musculoskeletal system disorders) and among veterans (athletes aged 50 years or over) [36].

In accordance with the rules, competitions are carried out with a circular system, mixed system, and a system of direct elimination, and the achievement is determined by personal, personal-team, and team results [15]. In the scientific and methodological sports literature, Keller and Platonov [3], Platonov [22], Matveev [16, 18, 24], Krasnikov [37], and Platonov and Bulatova [38] specifically described these methods, types, and levels of competition, which do not require further interpretation. It is worth noticing that competitions in mind sports have their own specificity, which is related to [15]:

- types of competitions: face-to-face (basic, qualifying, rating, commercial - simultaneous play, simultaneous blind play, etc.) or correspondence (by mail, by e-mail, by phone, online, by SMS);

- the conduction system: Swiss system, Scheveningen system, McMahon system, Silli system (holding correspondence competitions; developed by an Italian chess player Silli);

- determination of the sports result: by personal meeting, by the highest number of meetings won or victories, by points scored per game or match, by increasing points, and by a system of coefficients (Son-
neborn-Berger system of coefficients, Berger system of coefficients, Buchholz system of coefficients, Solkoff system of coefficients, Riga system of coefficients, Coya system of coefficients).

Championships, cups, tournaments, matches, match tournaments, the Chess Olympiad, the World Bridge Games, and others are held under the auspices of international sports federations with the support of SportAccord International Convention (currently Global Association of International Sports Federations) and the International Olympic Committee. Since 2008, under the auspices of the International Mind Sports Association and SportAccord, with the support of the International Olympic Committee, face-to-face complex competitions of World Mind Sports Games have been held, involving chess, checkers, bridge, Go, and xiangqi (Chinese chess) [39].

\section{Sports training as the 'subsystem' basis of integrated mind sports preparation}

Sports training as a 'subsystem' of sports preparation is a specialized process based on the use of specific means of developing mental and intellectual abilities, the formation of knowledge and technical skills, tactics, and strategy of the game. The main and complementary aspects of the preparation are intellectual, specially practical, and psychological. Physical preparation acts as an auxiliary component and is aimed directly at improving health and increasing physical activity. In addition, depending on the tasks of the preparing parties, specific means and methods of sports training are used (Figure 2) [40]. 


\section{HUMAN MOVEMENT}

N. Dolbysheva, Training in mind sports

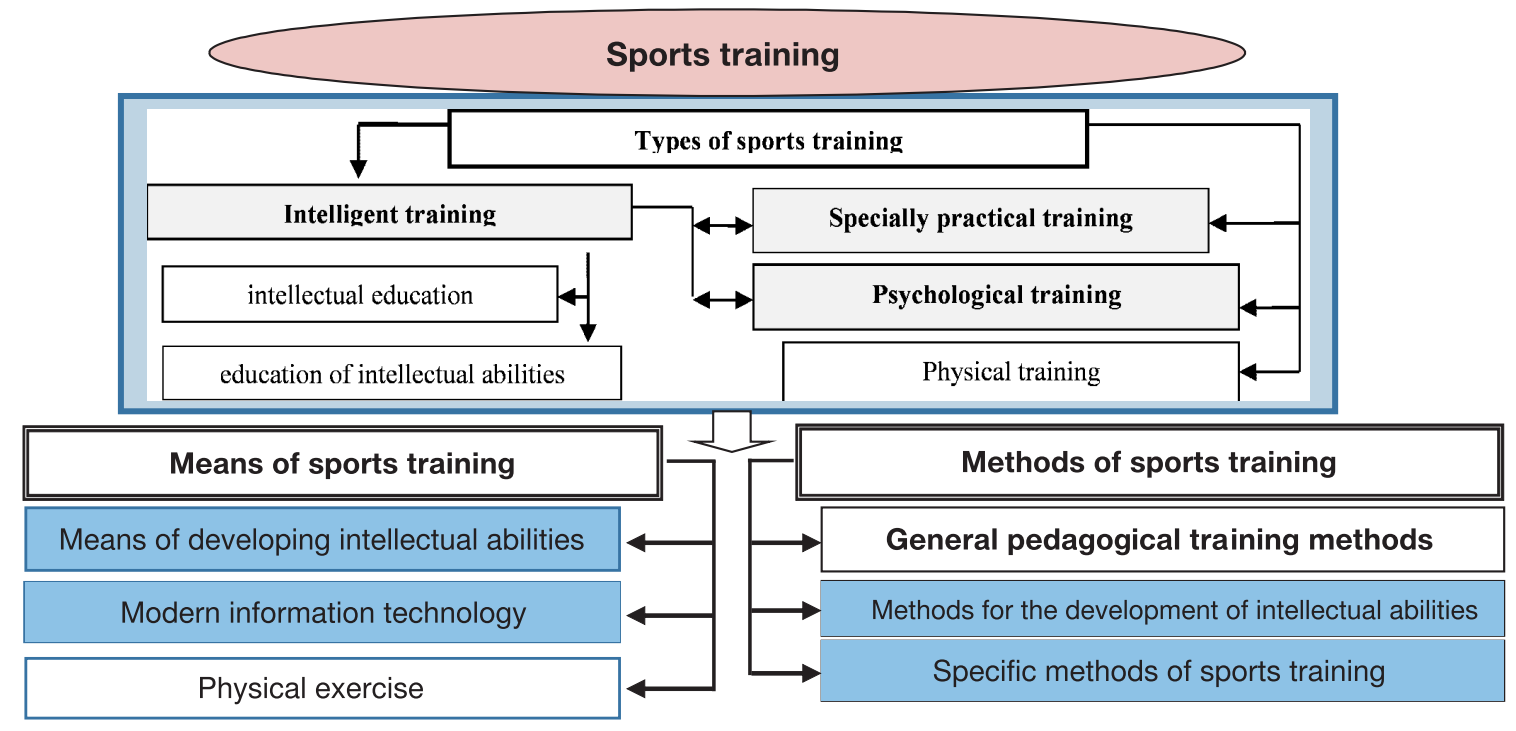

Figure 2. Components and contents of sports training in mind sports [15]

\section{Intellectual preparation}

As Platonov and Sahnovskiy [23] note, intellectual preparation is aimed at the formation of: creative activity, which is reached by means of an athlete's participation in the training process planning, the implemented plan analysis, studying own progress and failures in the course of training and competitive activity; an outlook on contemporary sport, knowledge of objective regularities of training and competitive activity on the basis of interdisciplinary sciences; abilities to creatively carry out analysis using methods of comparison, generalization, forecasting the quality of training and competitive activity. All this allows to improve thinking processes and expand cognitive activity.

In training programs for children and youth of sports schools, specialized schools of Olympic reserve for children and young people, schools of the highest sports excellence in checkers and chess of Ukraine, only theoretical preparation is implemented, which is erroneous [41-44]. This is stipulated by the fact that an athlete's intellectual training covers all aspects aimed at the awareness of sports activity, directly connected with the phenomena and processes. It has a direct link to the formation of an athlete's motivation and strong will, special mental preparation, learning the sport technique and tactics, improvement of sports game skill. Considering all aforesaid, intellectual preparation involves intellectual formation and the development of mental abilities (Figure 3).

Matveev [24] states that intellectual education is associated with the educational aspect aimed at knowledge transfer and is included in the range of theoretical training. Pityn [45] points out that theoretical training, on the one hand, is an independent struc-

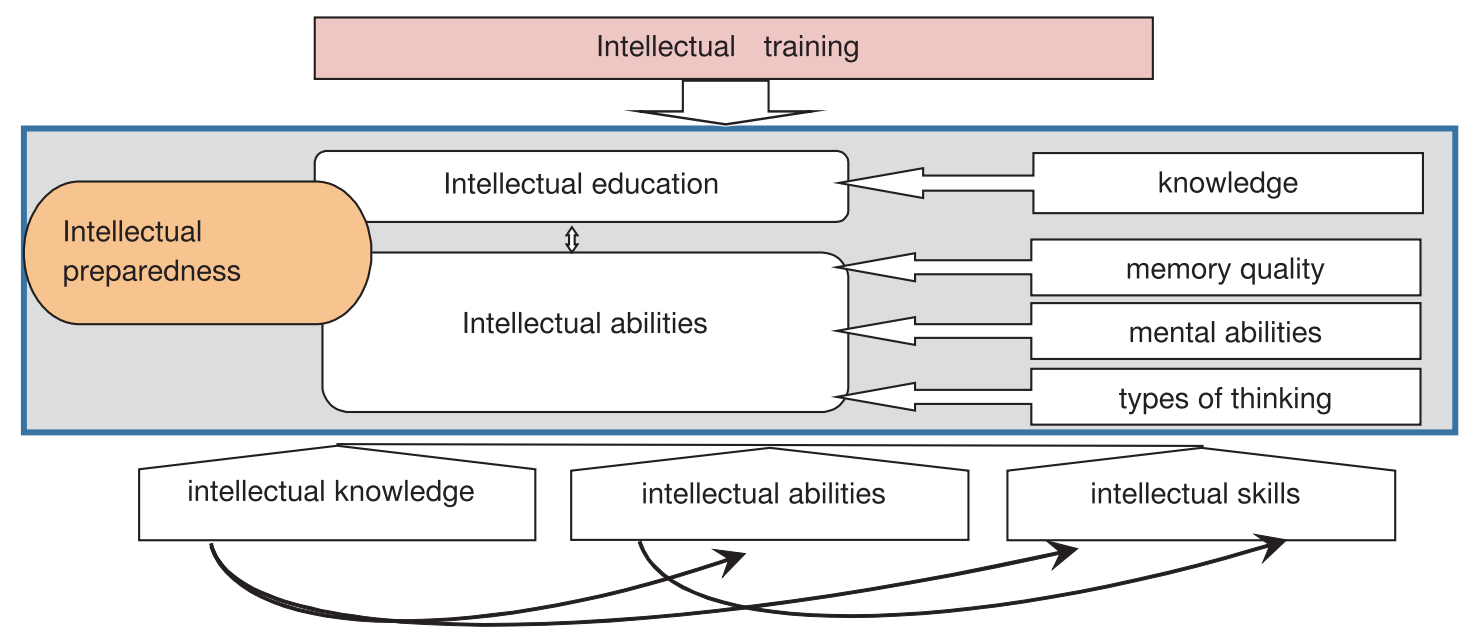

Figure 3. The structure and components of intellectual training 
tural unit, with the intellectual being its component, and on the other hand, it is an integral part of intellectual preparation and forms the basis of specially practical training.

Intellectual education covers a complex of world outlook knowledge, of motivational, sports, and ethical character, facilitating creation of world vision as a whole, allowing to realize the general nature of sports activity, its public and personal value for an athlete, forming the basis of steady stimulus to sports activities and the principles of sports behaviour; it also consists in gaining knowledge of special and applied character, including specific data on competition rules, sports technique and tactics, efficiency criteria and ways of learning through means and methods of a sports training, features of the training process, requirements of day regimen organization, rules of self-control, peculiarities of material support in the course of sports activities, etc.

The transfer and acquisition of theoretical knowledge in the course of mind sports athlete training is carried out in accordance with scientific and methodical approaches described by Pityn [45]. However, the paramount value of theoretical classes remains self-education and education of cognitive interests [41, 43, 44].

The process of athletes' intellectual education is accomplished on the basis of the linear and concentric (combined) methods of educational and training classes. The linear method presupposes teaching topical theoretical and practical material by gradual accumulation of information and tasks complication in line with the program. The concentric method provides studying of thematic sections not in a row one after another, but part by part, which allows the trainer to make theoretical classes more versatile and to cover one, two, or more subjects from each section at once within a certain period [41, 43, 44].

The second aspect of intellectual preparation is mental abilities training as the highest degree of cognitive activity in sports practice in general [14]. Mental abilities of an athlete must be expanded by strategy development and implementation, with the consideration of a game (problem) situation and ability to search for various options of the decision.

The intellectual abilities training is stipulated by the development of memory quality, mental abilities, and thinking [40]; these directly affect specific competences formation in a mind sports athlete.

Thus, intellectual abilities are characterized by: concentration of attention during the training process and competitive activities; ability to promptly process the information obtained and implement it in a game situation; aptness to memorize, store, and reproduce information; capability to think and argue; ability to quickly make decisions on the game move acting ahead of the opponent; talent to conduct a comprehensive analysis, evaluate and plan the training and competitive activities; ability to compare and productively solve problems arising in the process of playing activities, etc.

For an athlete to achieve the necessary level of mental abilities, it is essential to use means which contribute to their development, first of all, intelligence. Those are thrilling, didactic, subject, and role intellectual games, as well as solving intellectual tasks represented by verses, puzzles, crossword puzzles, schemes, basic tables, etc. The most effective method is the combination of a verbal method with its visual aid, variable and repeated performance of a task, a method of individual tasks, circular training in the form of schemes, symbols of intellectual and game exercises with consecutive change of complexity (intellectual load), along with a debate method, brainstorm, rapid-quiz questions, démarche, work with literature and on a computer, viewing game parties and analysing own actions while performing intellectual tasks and game parties [41, 43, 44, 46, 47]. The selection of methods and means depends on the preparation stage.

Intellectual preparation of mind sports athletes is done via intellectual (theoretical) knowledge, intellectual abilities, and intellectual skills [40]:

- intellectual (theoretical) knowledge is a set of theoretical and practical data on the general and special technique regularities, tactics, and strategy of a game, along with the scope of information on their utilization to accomplish the set objectives or achieve a certain result;

- intellectual abilities refer to processing, systematizing, and generalizing game material for the account of mnemonic processes, imagination, thinking, and its quality;

- intellectual skills are, on the one hand, an automated way to solve game problems in new or unusual conditions of a game situation that arise in competitive activities; on the other hand, these involve distributing, switching, and maintaining attention during training and competitions.

The implementation of intellectual knowledge, skills, and abilities in athletes is carried out through the cause-consequence links of the training process, which are based on age-specific psychological characteristics, basic principles of training, the sequence of tools use, intellectual training methods, and the competitive experience formation.

We note that in the course of cultivating intellectual 


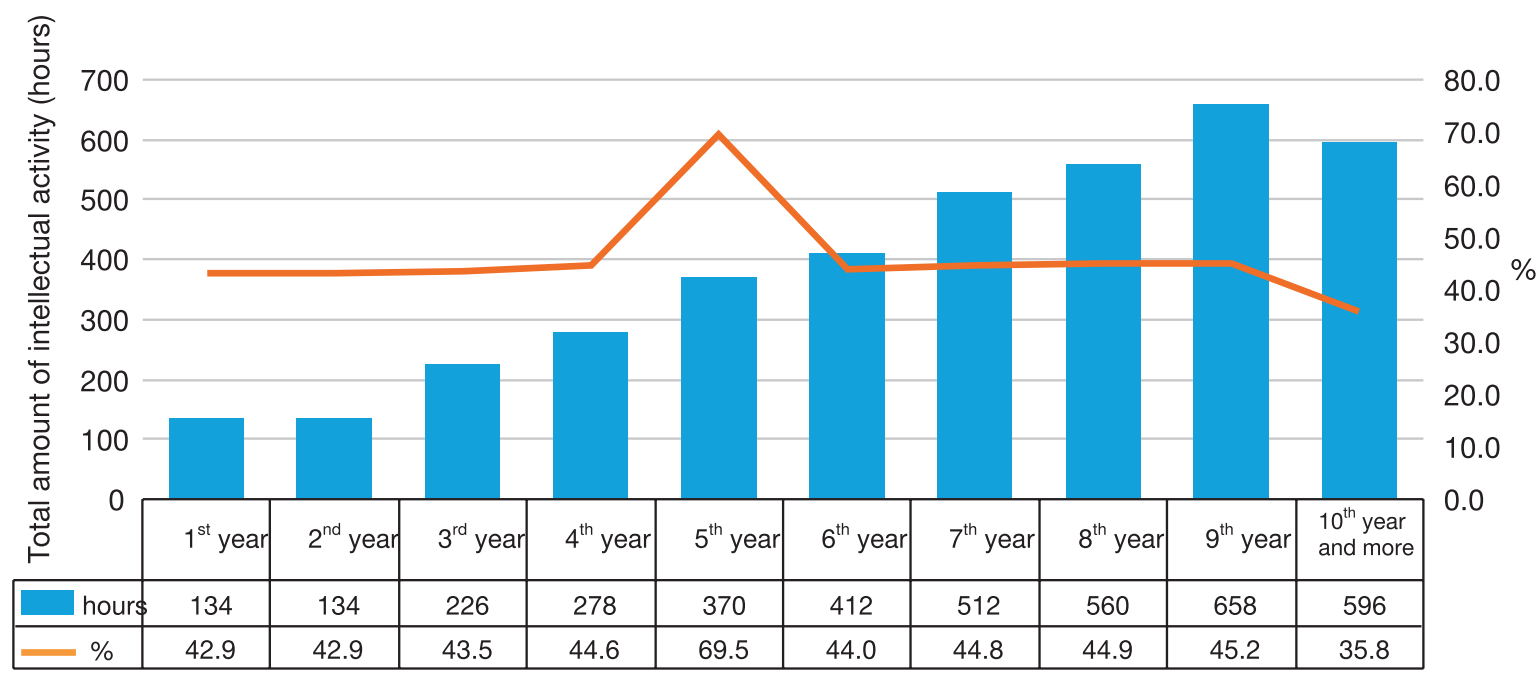

Figure 4. Intellectual preparation planning

abilities, it is vital to adhere to the following principles: gradual rise of work amount with intellectual information, increase of the independence level in performing intellectual tasks, expanding the integration of knowledge and intellectual methods, compulsory training in reasoning using variation and complication of intellectual tasks, formation of creative abilities.

The analysis of normative documents and scientific research suggests that the total annual time devoted to intellectual training is $35.5-69.5 \%$ (Figure 4). The frontal, group, and individual methods of organization are applied, with the individual one presenting a significant advantage [41-44].

Intellectual preparation is of a rather great importance at the age of $10-11$ years $\left(5^{\text {th }}\right.$ year of training; $69.5 \%$ of time), when the second stage of intelligence development - the precise and operational one - comes to its completion and the third one begins - the formal and operational one. The precise and operational stage is characterized by egocentric thinking linked to an interiorization of actions, completion of symbolical thinking development, semiotics functions, thinking by visual images of objects. The second level of mental development in the context of certain operations functioning comes to its end as well. The formal and operational stage is connected with manifestation of abilities to argue hypothetically, irrespective of the subject matter content due to formal and abstract thinking, to develop scientific theories using the deduction method, to carry out conclusions (reasoning) by rules of formal logic and combination theory, allowing the adolescent to produce hypotheses, think out experimental checks, and draw conclusions [48, 49].

We state that after the $9^{\text {th }}$ year of training, i.e. at a stage of sports skill increase, the volume of intellec- tual preparation training load falls down to $35.8 \%$. It is caused by the fact that the educational and training process emphasizes the improvement of specially practical and psychological preparation, which directly influences the achievement of highest sports results at the international level.

\section{Specially practical training}

Specially practical training is stipulated by the solution of tasks related to the formation and implementation of techniques, tactics, and strategy of the game through learning via playing, competitive and analytical practice $[41,44]$. This training is aimed at achieving fitness on the basis of the cerebral cortex preparation to store a wide range of knowledge associated with game practice [47].

Learning via playing practice is aimed at the formation of knowledge and skills in technical and tactical means affecting the game strategy and implementation of the following competitive activity objectives:

- position assessment: assessment and control of own game positions and the opponent's positions;

- combinational foresight: finding extraordinary, but effective moves and variations with subtle nuances that may significantly alter the game situation;

- evaluation technique: assessment of possible options and planning game actions;

- positional game: game style determination in accordance with objective estimates of the elements used in the practical game in order to set the most appropriate action plan;

- positional feeling: the ability to thoroughly understand the playing position, find and highlight its main features that have a crucial role in its assessment; 
- manoeuver restriction: determination of the game position which prevents from performing various options of game actions, but requires the player to take only a few actions or to implement protection [50].

It should be noted that technical-tactical methods are interrelated and, depending on the level of their mastery, they directly impact on the game strategy. For example, having evaluated a position, an athlete uses combinational vision with the subsequent use of assessment techniques, moving to a positional game in order to limit the manoeuver for the opponent [50].

Such notions as strategy, tactics, and technique of the game cannot be ignored:

- game strategy: a developed plan whose implementation is aimed at the performance of specific game moves and operations taking into account the game position and its evaluation, with planning the final goal (the struggle for victory or a draw) through various methods of achieving it (game aggravation, bluffing, etc.) [51, 52];

- game tactics: a system of techniques (primarily applied game combinations) allowing to achieve benefits and bring the game to a victory or a draw, which include distraction, luring, protection ruining, etc. [51, 52];

- game technique: basic laws of game actions performance technique (game moves) in accordance with the rules of the competition [52].

Strategy is directly linked to the game tactics, regardless of the fact that strategy is always abstract, while tactics is precise. The use tactical tools is intended to achieve strategic goals, as well as create the structural basis for the tactical strikes use through game combinations. Parties played in a tactical style are called combinational [22].

In the process of training-match practice, the major means are topical (analogical and analytical) game tasks with a variety of technical and tactical techniques, competitive and heuristic tasks related to creating new options of technical and tactical game actions, special tasks related to assessing options by using computer games and computer programs, and test tasks for the game strategy.

With the consideration of the nature of competitive activity and the peculiarities of training-match practice, the following pedagogical and specific teaching methods are used [6, 11, 41, 44, 53]: verbal, demonstrational, repeated performance of game tasks in accordance with the solution of thematic tasks (analogical, analytical, competitive, and heuristic), variable performance of game tasks, contemporary technologies, information bases, modules, encyclopaedias, etc., copywriting [54], circular training, game, competition.

The peculiarity is that while performing various types of individual or group tasks, mind sports athletes use scientific search methods [46, 55]:

- random search: associated with the search for new ideas for solving thematic problems that arise independently of their previous solutions, even when they are non-standard, extraordinary, not common and do not correspond to all the game laws; this, in turn, contributes to the development of intellectual abilities, creativity, extraordinary thinking, and intuition;

- algorithmic search: connected with the consecutive performance of topical assignments and new consecutive solutions enabling to form the skills of selfcompiling sequential actions for practical game activity with obligatory control and, if necessary, corrective actions;

- systematic search: associated with the execution of consistent, targeted, accurate assessments on implementation of all possible game strategy options and their combinations in terms of novelty, as well as determining the uniformity of solutions and their final result, followed by filtering and eliminating unnecessary game options for combining options and building game models.

Competitive practice involves solving problems associated with the consolidation of knowledge, skills, and abilities referring to technical and tactical methods and their implementation in competitive activities in order to achieve a sporting result. Also, this practice allows solving problems associated improving intellectual abilities and psychological qualification, especially distress tolerance.

The competitive method is the core tool of competitive practice, directly related to the organization and holding of competitions in the form of games, matches, and tournaments [55].

Analytical practice as no other facilitates training the ability of thinking independently. Its range is extremely wide and also connected with: systematic familiarization with specialist literature; studying game styles features, schools and directions; learning the concepts of game tasks and etudes; independent (or with the guidance of the trainer and group members) analysis of tournament and match parties, typical positions; development of debut systems; consideration and assessment of the rival's game; analysis of postponed parties positions; drawing up and replenishment of an individual game card file (computerized if possible), which includes the analysed debut systems, 


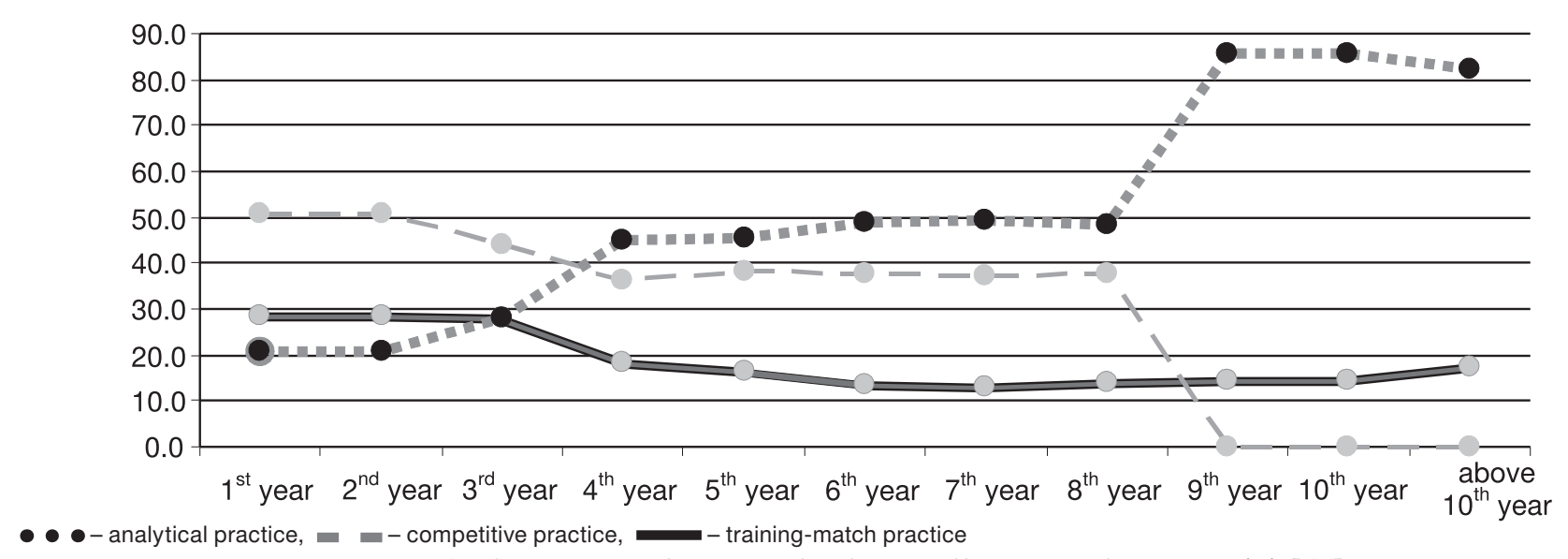

Figure 5. The amount of training load specially practical training (\%) [55]

theoretical positions, typical parties, creative characteristics of rivals, descriptions of already made analysis and other training materials [41, 44, 46].

The gained knowledge consolidation in analytical practice may take place in individual classes when an athlete performs analytical work independently, using scientific and search methods, and, as a result, submits the obtained outcomes in the form of papers, comments, etc. [41, 44].

The efficiency of the educational and training process of specially practical preparation depends on the utilization of an integrated approach connected with the complex training organization, including elements of methods of preparation and training listed above. Thus, in the course of complex training, it is necessary to integrate several different types of work, addressing the majority of training subjects at all learning levels, but to more complicated extent [41, 44].

Individualization of training plays an important role in specially practical preparation and enables to increase the educational process efficiency in terms of psychological preparation, including indicators of thinking, verbal analogy, memory (acoustical, visual, mechanical, motor), and attention (volume, concentration, and stability). Besides, the performance of individual educational and training homework of different complexity allows forming steady interest and skills of self-control and own activity assessment, as well as developing cognitive activity and creative abilities of the person [5].

The planning of specially practical preparation depends on an athlete's specific features, intellectual education level and mental abilities development, the academic load of the general time for the training, the preparation stage, the competition schedule, etc.

The scope of specially practical preparation, in line with the training programs for children and youth sports schools, specialized schools of the Olympic reserve for children and young people, and schools of the highest sports excellence in mind sports, is identical to intellectual (theoretical) preparation. The difference lays only in internal contents and load distribution in accordance with the educational, game-related, competitive, and analytical practice [41, 44].

Within the first 3 years, a rather significant space is occupied by competitive practice $(50.7 \%)$, connected with the organization of competitions, in the course of which awareness of game rules and technical fundamentals with gradual accumulation of tactics knowledge are formed. The importance of competitive practice after 8 years of trainings is somehow lost. It is stipulated by the fact that specially practical preparation improvement is carried out within independent analytical practice (Figure 5).

The amount of training-match and analytical practice has a variable character. The training-match practice covers $28.4 \%$ of the general time allowed for specially practical preparation in the $1^{\text {st }}$ year of training and $17.6 \%$ in the $10^{\text {th }}$ year of learning. In turn, analytical practice is planned for $20.9 \%$ and $82.4 \%$ of time, respectively.

Analytical practice in athletes from 14 years of age (the $9^{\text {th }}$ year of training) makes a basis of the entire preparation system, occupying one of the most significant places. Only through the analysis and synthesis, comparison and induction, deduction and modelling of game (competitive) activity, is it possible to gradually reach the cognitive discipline, on which the speed and quality of a game directly depend. Such planning is connected with the peculiarities of intelligence and thinking development [47] and a gradual transition to independent improvement of sports skills and the accurate goal setting linked to the best sports result achievement. 
In the course of the specially practical preparation, along with intellectual preparation, on the account of practical knowledge, technical-tactical and strategic skills formation occurs - the process of improving mental abilities, quality of memory, and thinking.

As competitive activity in mind sports is connected with abstract and logical thinking, the main work lays in the central nervous system and the cerebral cortex activity, which in turn influences a mind sports athlete's mental condition and demands from him high distress tolerance, concentration, etc. Therefore, psychological preparation is closely linked to intellectual and specially practical preparation and occupies one of the main positions in the educational and training process [15, 40, 55, 56]. Vysochina [57] states that achieving sports results depends on psychological provision of the entire system of athlete training.

\section{Psychological training}

Psychological training of mind sports athletes, as indicated by van Zung and Linovitskiy [7], is a purposeful psychological and pedagogical process carried out through selective and individual use of mental loads contributing to the development of mental qualities and personality conditions most significant for sports activity.

There is a general (strong will) and special preparation in mind sports, as in theories of dynamic sports preparation. The distinctive feature of the general psychological preparation is that it is directly integrated into other preparation types and has practically no own tools for implementing its purposes and tasks. Its main objectives are: forming positive adaptation to specific loads and conditions of the training and competitive process; updating the athlete's potential opportunities and reserves for effective training and competitive activity; forming and developing personal mental qualities of the mind sports athletes with the consideration of the specifics of competitive activity; creating tolerance to stressful situations and perception of param- eters aimed at the implementation of mental activity in a game situation; shaping brain structures for pro-active reactions and real actions vital for efficient competitive fight; improving the ability to operate in personal interactions with the partner or rival.

Special psychological preparation is an important component in the formation of an athlete's integral readiness to participate in competitions and achieve sports results. It is directed to creation of operational mental readiness and encourages the maximum implementation of intellectual, tactical and technical, functional, and physical capacities in the course of a sports fight. It also ensures assessment and correction of mental states, accounting for specific features of a sports competition, in particular its signs, conditions, and some other factors. For this purpose, it is necessary to be able to analyse precisely the competitive conditions and features of physical and mental activities, as well as distinguish the major move qualities, competitive action features, determination, and other important points, signs, situations which define successful performance of the tasks set for the mind sports athlete [7].

The formation of an integral condition of mind sports athletes' mental readiness for responsible competitions passes through 3 stages of psychological preparation (Figure 6).

While planning psychological preparation, it is necessary to consider a certain level of psychological readiness achievement of mind sports athletes, directly connected with:

- other types of preparation (intellectual, specially practical, physical, and integrated);

- preparation for specific competitive activities;

- formation of only those personality traits of an athlete which provide a high quality of intellectual activity;

- structural components of psychological readiness, determined by the mechanisms of emotional, intellectual, and strong will development, as well as mental readiness for self-regulation and self-management of their conditions [13, 15, 41, 44, 58].

Stage 1: general psychological preparation

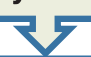

Stage 2: special psychological training

$\mathrm{Y}$

Stage 3: correction of psychological readiness for specific competitions

Result: complete mental (military) readiness

Figure 6. Stages of psychological training in mind sports [41, 44] 
During the psychological preparation, it is necessary to take into account psychophysiological indicators (memory, mental stability, functional capabilities of the nervous system, activity of neurovegetative regulation of heart rhythm at rest and under mental load), which change under the mental activity impact [48].

According to the curricula of schools for children and young people in Ukraine and programs of foreign countries for mind sports athletes, the psychological preparation includes the following [41, 44, 59]: objective psycho-diagnostics in the system of selection and preparation; basic psychological preparation which comprises mental functions and qualities of development, specifically important for a mind sports athlete, such as critical thinking, attentiveness, memory, imagination, ability to analysis and introspection, determination, initiative, etc.; psychological education (formation of a special knowledge system of a person's mentality); formation of abilities to regulate the strongwilled state, to get concentrated before the match, to mobilize forces during the match, to resist adverse effects, etc.; psychological preparation for classes which provides their maximum efficiency; psychological preparation to competition, based on fundamental preparation which provides optimum readiness to fight.

Vysochina [13, 57] specifies that in the course of psychological preparation, it is necessary to pay attention to manifestation of psychological states which allow overcoming mental loads in the conditions of extreme (competitive) activity; this facilitates the formation of knowledge, development of effective selfcontrol skills in difficult conditions of competitive fight. The mental state in sports activity is connected with the manifestation of mental reactions to the current training and competitive load and has an adaptive nature that influences the formation of a pre-starting state.

Kozlova [60] scientifically acknowledged that a prestarting state and the respective sports result depend on unconscious interaction of the right and left brain hemispheres. Also, high performance of competitive activity is ensured by synchronization of specific psychophysiological processes, including a certain level of autonomic nervous system anxiety, emotional and functional balance of central and peripheral nervous systems.

Besides, the educational and training process efficiency, in accordance with the manifestation of creative activity, is reached at the account of interest and the athlete's positive mood, close interrelation between the intellectual and emotional spheres and use of the selective and individual mental loads, allowing the formation of mental qualities and their states.

The major form of the psychological preparation organization is carrying out thematic and practical trainings. Thematic classes are conducted in subjects: confrontation psychology, psychological interaction of opponents, psychology of the attack and protection, problem of risk, intuition problem, risk situations classification, game psychology in positions of dynamic balance, etc. Practical training aims at the decisive parties analysis of the main tournaments and matches, planning of 'a game component,' which contributes to the development of attention concentration and consequently leads to stimulation of the right and left cerebral hemispheres activity [10], development of psychophysiological functions in mind sports athletes [47], adaptation to the changing environmental conditions, and adequate reflection of time, forming motor memory at the same time [59,61].

In the course of psychological training of mind sports athletes, the following methods are used: verbal influence, performance of feasible tasks for result achievement, input of situations demanding overcoming difficulties, concentration before competitions, encouragement, performance of public and personal instructions, punishments, scaling of time spans duration, game practice.

In the process of mental preparation, control plays an important role, which is carried out at all stages of long-term preparation. At the stage of basic preparation, it is necessary to perform diagnostics and monitoring of mental processes, such as: attention, memory, thinking, imagination, perception, sensation etc. For example, for the diagnosis of attention, the Riesz test, Gorbov method, and proof-reading are used; for memory: memorizing 10 words (Luria), Jacobs test (for the amount of short-term memory); for thinking: Ebbinghaus test (filling in the missing words in the text), ability to count in the mind, method for determining concepts, identifying causes, identifying similarities and differences in objects; for imagination: verbal fantasy, depiction, sculpture, 'Where is whose place?', 'Think of a game'; for perception and sensation: recognition of figures, 'What is missing?' (Nemov), information search, Tikhomirov method, flat figures according to Falkelt (visual and tactile perception), Thorndike test (perception selectivity), scythe cubes (spatial perception); for perception: Muller method, maximum measurements, constant method, and others. At the stage of profound preparation, it is necessary to diagnose personal qualities with the Kettell 
questionnaire (16-RF), individual psychological characteristics personality traits with the Eysenck test, personal values with the Edward scale, and character traits with the Schmishek test. At the stages of sports improvement and sports skills, one should monitor the level of psychological preparedness with the method for assessing sports psychological preparedness (UMBC), anxiety with the Spielberger-Hanin questionnaire, adaptive abilities, neuropsychic stability and moral normativeness with the adaptability questionnaire (by Maklakov and Chermyanin), and others.

Thus, the main objectives of psychological training of mind sports athletes are: forming significant moral and strong-will-related qualities; improving attention; mastering ability to concentrate and be mobilized during the training and competitive process; forming abilities to control feelings, actions, emotions, and behaviour; improving abilities to regulate the mental state during the training and competitions and also to resist adverse effects of external and internal factors; developing abilities of introspection, self-criticism, selfrequirements, self-confidence; developing the athlete's intelligence; creating readiness for competition performance; learning victory targeting.

\section{Physical training}

In the general sports theory, physical training is considered one of the important components of sports training that aims to strengthen the athlete's body and organs, increase functionality, and develop physical qualities: endurance, force, speed, flexibility, coordination abilities and their manifestations (types) [3, 16, 23, 38, 62].

Physical training of mind sports athletes is auxiliary. The purpose is physical development due to the impact on the morpho-functional qualities of the organism, increase in the general working capacity, general improvement of health, strengthening of the main physiological functions of the body, and keeping to a healthy lifestyle. Physical training allows to get the appropriate functionality level and reach the ability to maintain high intellectual and emotional loads (for example, competitions on average last 9-16 days, up to 9-12 hours a day, and match duration is 1.5-6 hours or more). Of great importance are the level of special endurance development, and the condition of cardiovascular and respiratory systems.

Planning of physical training is mandatory as considerable intellectual loads cause excessive fatigue of the nervous system. Physical exercises are means to switch from one activity to another; they promote faster rehabilitation of mental activity and boost of physical activity, strengthen the cardiovascular and respiratory systems, and improve health in general.

The amount of physical training in the training process at the $1^{\text {st }}$ stages (basic and in-depth training) should cover not less than $10-25 \%$ of the total time. A significant amount of physical training load (50$60 \%$ ) falls on the transition period, which provides maximum physical activity during rest, allowing to reach health improvement, special endurance, as well as a high level of emotional-volitional parameters, motivational priorities, and functional preparedness for the start of a new 1-year training cycle and the competitive season [8].

Classes in physical training have to be carried out under the guidance of a specialist coach, and when performing physical exercises, extreme loads must be avoided. At the stage of sports skill rise, physical training switches to independent work.

The main means of physical training are a variety of sport games and physical exercises aimed at the development of physical qualities and strengthening the cardiovascular and respiratory systems. Additional methods of physical training are morning hygienic gymnastics, outdoor games, swimming, hiking, rhythmic and athletic gymnastics, etc. [8].

Numerous studies of sports-pedagogical and biomedical sciences allow to clearly select and develop a methodology for the physical qualities development depending on the athletes' age and gender characteristics. However, the selection of tools and methods for physical qualities development in mind sports should be carried out to a greater extent in accordance with their sensitive periods. Also, when planning physical activity associated with physical qualities development, it is necessary to take into account the children's level of health, i.e. the medical group to which they belong [42].

To assess the level of physical fitness in mind sports athletes, control (motor) tests are used, e.g. shuttle run $3 \times 9 \mathrm{~m}$ (age of 7-9 years) to evaluate agility; 300-m (7-9 years), 500-m (10-12 years), and 1000-m run ( $\geq 13$ years) to evaluate endurance; flexion and extension of the arms in the resting position (since 7 years) to evaluate strength; torso forward in a sitting position (since 7 years) to evaluate flexibility; $30-\mathrm{m}$ (7-9 years) $60-\mathrm{m}$ (10-11 years), and 100-m run ( $\geq 12$ years) to evaluate speed; standing long jump (since 7 years) to evaluate speed-power ability. 


\section{Stages of long-term sports training}

The many years of training in mind sports include: achieving a high level of practical skills; obtaining a fundamental amount of theoretical knowledge; mastering the ability to carry out practical analysis and research work, which is the basis for improving the game rank and sports results; moral, psychological, and physical training; acquiring deep intellectual culture in the knowledge areas of history, classical heritage foundations, traditions of Ukrainian intellectual school; improving the abilities of working with a book and using computer equipment [41, 43, 44, 46, 63].

The basis of long-term preparation in mind sports is made of: generalized theoretical and methodical, scientific and practical knowledge reflecting and revealing achievements of athletes at the world level depending on their training duration; knowledge of age and gender anatomy, physiological and psychological features of athletes; links between contents and means of sports preparation throughout a sports career; features of fitness formation, various aspects of preparation and adaptation of the main functional systems on the basis of sports, pedagogical, medical, and biological regularities; experience of participation in competitions.

A generalization of the actual material allows to establish that long-term preparation in these sports has a specific distribution, which covers 4 stages: a stage of basic preparation, a stage of profound preparation, a stage of sports improvement, and a stage of sports skills improvement. Such an approach to the structure of long-term preparation coincides with the creation of preparation process by Nabatnikova [64], which is based on the methodical approach focused on the highest result achievement within age restrictions, i.e. phases of an athlete's optimum capabilities.

The structure of long-term preparation in mind sports is presented in Table 4 [65]. The stages, on the one hand, rectilinearly depend on intellectual qualities development, and, on the other hand, are stipulated by the rectilinear movement from one stage of development to another on 'spirals,' which are subject to reconsideration, restructuring, integration, and union at higher level. Thus, the main criteria affecting the structure of long-term preparation are features of intellectual and psycho-emotional development in the age aspect, the sensitive periods of mental abilities development, which are not just increasing with age, but also changing [42].

The features of the 4-stage structure of a long-term process of mind sports athletes' preparation stems in the definition and follows the 3 levels of training: initial - characterized by basic preparation, main fundamental preparation, highest - improvement of fundamental preparation [41, 43, 44].

The basis of training groups enrolment is the system of long-term preparation with the consideration of age and age regularities of sports skill formation, week load increase and transfer of children to the subsequent groups of training, sports experience, the number of sports classes, implementation of control standards for the general physical training, and sports results positive dynamics [20, 22, 41, 44, 63]. The general structure and duration of the long-term preparation in the age ranges allowed to systematize the training process in relation to the number of pupils in groups, weekly class hours, requirements to sports preparation along with tasks, means and methods in accordance with the regularities and principles of sports training [63,65].

The general total educational training load for an academic year is defined as 52 calendar weeks. However, planning of the load at the stages of basic and profound preparation is carried out on the basis of 46 weeks of classes for children and youth in sports

Table 4. The structure of many years of training in mind sports [65]

\begin{tabular}{|c|c|c|c|}
\hline $\begin{array}{l}\text { Stages of long-term } \\
\text { preparation }\end{array}$ & Stage duration & Preparation stage goal & Preparation level \\
\hline $\begin{array}{l}\text { Stage 1: basic } \\
\text { preparation }\end{array}$ & 2 years & $\begin{array}{l}\text { Determining abilities for mind sports learning, } \\
\text { forming basic game preparation }\end{array}$ & Starting \\
\hline $\begin{array}{l}\text { Stage 2: profound } \\
\text { preparation }\end{array}$ & 4 years & $\begin{array}{l}\text { Mastering fundamentals of the game technique, } \\
\text { profound mastering of game tactics and strategy }\end{array}$ & \multirow{2}{*}{ Basic } \\
\hline $\begin{array}{l}\text { Stage 3: sports } \\
\text { improvement }\end{array}$ & 3 years & $\begin{array}{l}\text { Profound mastering of the game technique at all stages, } \\
\text { forming the individual 'debut repertoire' }\end{array}$ & \\
\hline $\begin{array}{l}\text { Stage } 4: \text { sports skills } \\
\text { improvement }\end{array}$ & $\geq 4$ years & $\begin{array}{l}\text { Improving game skills, developing necessary } \\
\text { strategic skills, forming character }\end{array}$ & Top \\
\hline
\end{tabular}




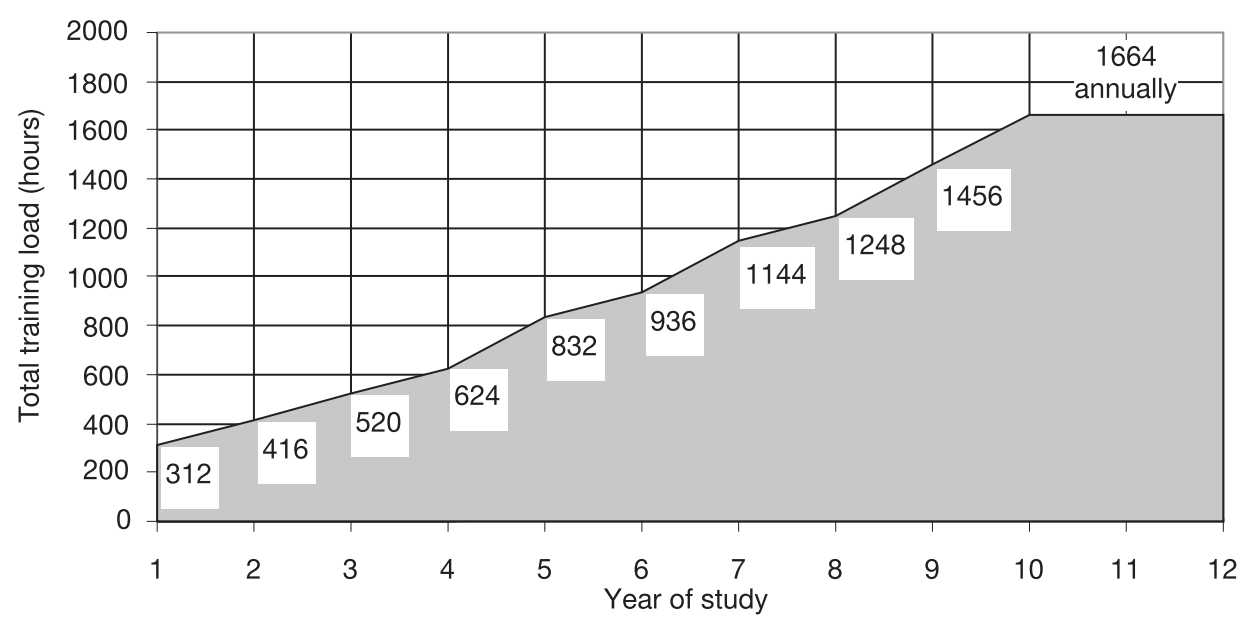

Figure 7. The total volume of workload planned in mind sports (per year) [65]

schools and 6 weeks of camps during active summer holiday. At the stages of sports improvement and sports skills improvement, the load is variable owing to the systematic participation in competitions, which impacts on the training process and individual preparation program planning in the annual macrocycle (Figure 7).

Each preparation stage solves a number of general and specific tasks related to the formation of personality, basic and fundamental knowledge, skills, and abilities in accordance with the competitive activity and psychological and pedagogical features and specifics. To prepare an efficient and correct individual training load, it is necessary to diagnose the athlete's creative abilities, identify the disadvantages and advantages of their personality, thinking, and character. Medical, biological, and pedagogical follow-up is carried out annually for the monitoring of the athletes' health and level of physical fitness.

\section{Stage of basic preparation}

The basic training stage is important as a kind of preparatory period; during the first 2 training years, a proper foundation for future achievements is laid, i.e. the basis for further mastering the game intellectual craftsmanship. It involves children aged 6-7 years, presupposing the initial level of training achievement due to training sessions planned for 6-8 hours a week, and solving common tasks related to the basic knowledge and game technique fundamentals [65].

The mind sports classes start, as a rule, at the age of 6 years, which is stipulated by early specialization. Therefore, at this stage of preparation, it is feasible to carry out versatile development of intellectual and physical qualities by specially selected exercises di- rected to the development of memory, imagination, logical thinking, anticipation, ability to plan actions and make decisions. It is connected with the fact that at the age of 6 , intensive growth and development of all functions and systems of a child's body occur. At this age, children easily grasp the training material and the obtained practical skills are fixed for decades ahead [6, 58]. They also gain the ability to quickly familiarize with technically difficult positions, to exactly calculate the forced options, particularly under the pressure of time and surrounding circumstances, to intuitively find optimal solutions. However, the duration of active attention, concentration, and intellectual working capacity is small and does not exceed 15 minutes. Therefore, intellectual load is planned in little volumes and moderate intensity.

For the set objectives solution at this stage of preparation, theoretical and practical group training is provided.

At the basic preparation stage, competitions are organized at 2 levels: within groups and between groups, in order to form awareness with regard to the organization of competitions, basic competition rules, and culture of behaviour.

\section{Stage of profound preparation}

This stage covers 4 years of training for children aged 8-11 years, with training classes of 12-20 hours a week, aiming to achieve the main level of readiness while solving fundamental problems [65].

The solution of training process fundamental tasks requires profound sports specialization and a steady growth of training loads in volume and intensity. At this stage, physical training ratio decreases and the share of special preparation rises. Therefore, the training load 
is planned individually, with mandatory proper rest and use of different recovery methods. It is connected with the fact that mental abilities of children aged 8-11 intensively evolve and a considerable development is reached by the cerebral cortex. Children of this age are able to maintain increased intellectual loads and quite easily acquire complex theoretical material. However, domination of anxiety over braking reaction is often noted [41, 43, 44].

At this stage, children are able to dramatically improve their sports results, and in some cases reach the rank of a candidate for master in sports of Ukraine.

\section{Stage of sports improvement}

The stage of sports improvement covers 3 years of training for adolescents aged 12-14 years, with training sessions of 24-28 hours per week, during which further improvement of the basic training level is accomplished and the athlete is presupposed to solve specific tasks related to advanced training [65].

At this stage, sporting results are noticeably growing, in some cases even reaching the world level. This is stipulated by the fact that adolescence features a high level of functional excellence, readiness for significant physical and mental stress.

This stage is connected with considerable volumes and intensity of training loads, planned for necessary information processing through the analysis of own parties and rivals' parties played in competitions, as well as the analysis and preparation of debut options before competitions. For the purpose of sports skill improvement, the search is carried out for correct and at the same time deep, extraordinary, and objectively beautiful game solutions, resolutions of combinational tasks, and their application in a practical game. The significant amount of training loads is connected with work on personal computers, allowing the mind sports athlete to more effectively and promptly solve the combinational tasks set by the trainer, using various game options. A considerable role in the preparation system is played by participation in competitions; therefore, the training process gains a purely individual character, determined by the upcoming years' competition schedule. Physical training is considered only a recovery means and holiday activity.

\section{Stage of sports skills improvement}

This stage is divided into 2 training sub-stages. Athletes aged 15-17 years being trained at children's and youth sports schools of various categories pass the first sub-stage, which is aimed at achieving high sportsmanship, participation in continental and world level competitions, entering the international rating. The second sub-stage begins after the $12^{\text {th }}$ year of training, at the level of higher sportsmanship schools, at the age of 18 and over. The preparation assignments at this stage are more specific and associated with prospects for achieving results, in most cases of a world level [65].

Classes at this stage are carried out in accordance with individual plans, with the consideration of the preparation level achieved by mind sports athletes in the previous preparation stages. It takes quite a lot of time to work with specialist literature, computer programs, reviewing and analysing matches online and on Internet sites.

The sports skills improvement stage in mind sports has its specific features, primarily related to its duration, sports results dynamics content, and the transition to a professional level.

The sports career duration in mind sports has practically no age limits, since mind sports athletes are capable of maintaining their world-class achievements for 20 years or more, and their overall sports experience may reach 55 years $[65,66]$.

Thus, long-term training from a novice to the grandmaster level is considered as a single process that follows certain laws, considering the age characteristics and capabilities of an individual, and is based on the following methodological provisions:

- steady support of age limits for practicing mind sports and forming groups;

- no focus on high sports result achievement in the first years of the training process;

- training tasks solution in accordance with the stage and age peculiarities;

- developing mental qualities (memory, attention, creative imagination) and intellectual abilities (logical thinking, the ability to analyse and draw conclusions, make decisions, and foresee the results of the decisions taken) at each stage of preparation to form a reliable foundation for young intellectuals' success in line with sensitive age periods;

- carrying out continuous improvement of the technique and tactics of the game and its variations, utilizing specific means of sports training, such as specialist literature, computer programs, reviewing matches online, etc.;

- strict application of the gradual training, training intensification, and competitive loads principle in the course of multi-year preparation;

- mandatory support of a rational mode of training and learning in educational institutions; 
- implementation of health medical monitoring, as well as pedagogical monitoring of mental and physical stress, and intellectual and physical fitness.

\section{System factors of athlete training in mind sports}

The system of preparation and its 'subsystem,' the organization and holding of sports competitions and sports training in mind sports practice, tend to improve. This is linked with the fact that they are influenced by external and internal factors, which might be treated as system factors [66]. In our case, system factors, on the one hand, represent objective regularities of sports practice changes; on the other hand, they act as means for its improvement.

Figure 8 shows the system factors objectively influencing the entire mind sports preparation system, which tends to change internally and is directly associated with global trends alteration.

Each system factor can be considered both at the level of an independent unit [66] and in the complex context, since they complement one another and have close interconnections. For instance:
- the development of educational programs at the national and international levels promotes public awareness of sport, which in turn causes an increase in the number of athletes engaged in competitions, as well as geographical territoriality expansion;

- the formation of new disciplines leads to competition schedule extension and involvement of masters in competition data, which directly influences their overall competitive activities and the system of preparation on the whole.

\section{Conclusions}

1. The analysis of scientific-methodical and practical literature shows that mind sports constitute their own group in the sport general classification and are not included into the Olympic Games program. They are distinct from dynamic sports and characterized by the following:

- the competition result is achieved owing to an advantage or victory by using abstract-logical thinking;

- the training process and competitive activity feature physical activity absence and their loads are aimed at mental abilities implementation and intellectual

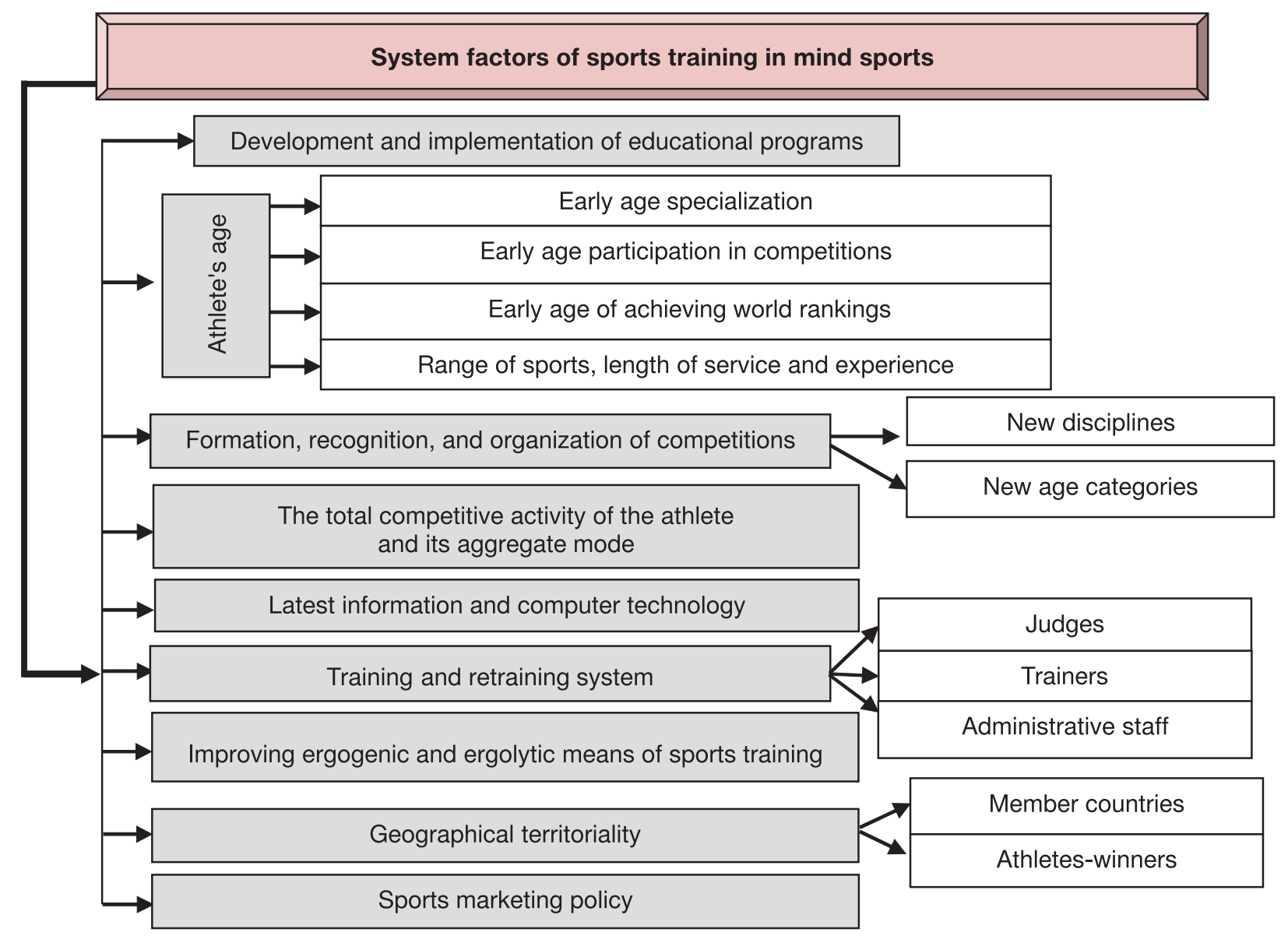

Figure 8. System factors affecting athletes' preparation in mind sports 
effort manifestation at the background of psychological stability;

- the training system aims to form special competencies through the implementation of principles and use of very specific sports training means and methods;

- sports training specific principles differ from those applied in physical activity training and focus on intellectual and mental loads;

- the training efficiency and sports result achievement directly depend on the level of mental qualities and intellectual abilities development;

- the core types of sports training are intellectual, specially practical, and psychological; physical training is auxiliary, aiming at health promotion, physical qualities development, formation of vital motor skills and abilities, increase of the physical activity level;

- the main achievements at the international level are international ranks nominations (Grandmaster).

2. Given the mind sports specificity, there is a need to consider the entire system and 'subsystem' of training mind sports athletes with their autonomy related to:

- features of arrangement and conduct of competitive activities;

- sports result achievement specifics;

- training process focused on forming competence and implementing specific principles of sports training (purely specific principles of educational and cognitive activity organization);

- usage of specific means and methods of preparation; features of preparation and their planning; use of extra-training and extra-competition rehabilitation tools, etc.

\section{Acknowledgements}

I herewith express my gratitude to the Doctor of Science on physical culture and sport, the leading Research Associate of Research Laboratory of Scientific Support for Physical Training and Sport Standards Development of the Research Centre for Physical Education Issues, Special Physical Preparation and Sports of the Educational Scientific Institute of Physical Culture and Sports Recreational Technologies of National Defence University of Ukraine named after Ivan Chernyakhovskyi, the International Master in chess among women, Nadezhda Leonidovna Vysochina; the First Vice-President of Federation of Checkers of Ukraine, the President of the Dnipropetrovsk region Federation of Checkers, the Master of Sports of the USSR in checkers, Urikh Evgeny Osipovich; the Master of Sports of Ukraine in checkers, the coach of Municipal Extra-Curriculum Educational Institution for Children and Youth Sports School No. 9 named after the international grandmaster A.S. Moroz of the Dnieper City Council, Anatoly Anatolyevich Panchenko - for assistance, consultations, positive reviews, and the interest shown in this direction of research.

\section{Ethical approval}

The conducted research is not related to either human or animal use.

\section{Disclosure statement}

The author does not have any financial interest and did not receive any financial benefit from this research.

\section{Conflict of interest}

The author states no conflict of interest.

\section{References}

1. Dolbysheva NG. The main directions of non-Olympic sports [in Ukrainian]. Sportyvnyi Visnyk Prydniprov'ia. 2014;2:31-39.

2. Dolbysheva NG. Scientific approaches to the classification of non-Olympic sports [in Ukrainian]. Sportyvnyi Visnyk Prydniprov’ia. 2014;1:138-144.

3. Keller VS, Platonov VM. Theoretical and methodological bases of athletes training [in Ukrainian]. Lviv: Ukrainska Sportyvna Asotsiatsiia; 1992.

4. Platonov VN. The system of training athletes in Olympic sports. General theory and its practical application: student [for coaches] [in Russian]. Kiev: Olimpiyskaya Literatura; 2015;1.

5. Anisheva VE. Methodical peculiarities of individualized initial training in chess for children of primary school age [in Russian]. Abstract of PhD dissertation in pedagogical sciences: 13.00.04. Moskva: Rossiyskaya Gosudarstvennaya Akademiya Fizicheskoy Kulturyi; 2002.

6. Bovaev CA. Technique for the formation of strategic skills of chess players at the stage of sports improvement [in Russian]. PhD dissertation in pedagogical sciences: 13.00.04. Volgograd: Kalmyitskiy Gosudarstvennyiy Universitet; 2011.

7. Van Zung D, Linovitskiy EP. Psychological features of the training process of chess players [in Russian]. Sportivnyiy Psiholog. 2005;1:35-38.

8. Ilchenko AA. Physical training of young chess players in the transition period of the annual training cycle [in Russian]. PhD dissertation in pedagogical sciences: 13.00.04. Volgograd: Volgogradskaya Akademiya Fizicheskoy Kulturyi; 2011.

9. Knyazeva VV. The structure and content of the chess subject in the comprehensive school system in Russia [in Russian]. PhD dissertation in pedagogical sciences: 13.00.01. Moskva: Rossiyskaya Gosudarstvennaya Akademiya Fizicheskoy Kulturyi; 2000. 
10. Kokshaeva AV. Methods of training young chess players at the stage of initial specialized training [in Russian]. PhD dissertation in pedagogical sciences: 13.00.04. Elista: Kalmyitskiy Gosudarstvennyiy Universitet; 2009.

11. Kyichkina AI. The development of creativity and imagination in students aged 11-14 when playing checkers [in Russian]. PhD dissertation in pedagogical sciences: 13.00.04. Moskva: Rossiyskiy Gosudarstvennyiy Unyiversitet Fyizicheskoy Kulturyi, Sporta i Turizma; 2005.

12. Vologan VA. The structure of the special preparedness of highly qualified chess players [in Russian]. PhD dissertation in pedagogical sciences: 13.00.04. Moskva: Rossiyskaya Gosudarstvennaya Akademiya Fizicheskoy Kulturyi; 1996.

13. Vysochina NL. Self-assessment of skilled chess players and its impact on sports performance [in Ukrainian]. $\mathrm{PhD}$ dissertation in physical education and sports sciences: 24.00.01. Kyiv: Natsionalnyi Universytet Fizychnoho Vykhovannia i Sportu Ukrainy; 2011.

14. Yunusov SY. Pedagogical bases of intellectual abilities development in schoolchildren by means of computer technology: on materials of the Republic of Tajikistan [in Russian]. PhD dissertation in pedagogical sciences: 13.00.01. Kulyab: Kulyabskiy Gosudarstvennyiy Universitet imeni Abuabdkulloh Rudaki; 2009.

15. Dolbyisheva NG. General laws of the system of training in mind sports [in Russian]. In: Olympic Sports and Sports for All: Proceedings of the XX International Congress (December 16-18, 2016, St. Petersburg, Russia) [in Russian]. Sankt-Peterburg: Izdatelsko-Poligraficheskiy Tsentr Politehnicheskogo Universiteta; 2016; 330-335.

16. Matveev LP. Fundamentals of the general theory of sport and the training system of athletes: a training manual [in Russian]. Kiev: Olimpiyskaya Literatura; 1999.

17. Deminskyi OT. Didactic fundamentals of sports training optimization [in Ukrainian]. Kyiv: Vyshcha Shkola; 2001.

18. Matveev LP. General theory of sport and its applied aspects [in Russian], $5^{\text {th }}$ ed. Moskva: Sovetskiy Sport; 2010.

19. Platonov VN. The system of training athletes in Olympic sports. General theory and its practical application [in Russian]. Kiev: Olimpiyskaya Literatura; 2015.

20. Bubka SN, Platonov VM (ed.). Olympic training system: fundamentals of management [in Ukrainian]. Kyiv: Persha Drukarnia, 2018.

21. Gaverdovskiy YK. Experience in the interpretation of orthodox didactics in the modern context of teaching sports exercises [in Russian]. Teoriya i Praktika Fizicheskoy Kulturyi. 1991;8:12-20.

22. Platonov VN. Periodization of sports training. General theory and its practical applications [in Russian]. Kiev: Olimpiyskaya Literatura; 2014.

23. Platonov VN, Sahnovskiy KP. Preparing a young athlete [in Russian]. Kiev: Radyanska Shkola; 1988.
24. Matveev LP. Fundamentals of sports training [in Russian]. Moskva: Fizkultura i Sport; 1977.

25. International Chess Federation. Available from: https://www.fide.com/.

26. World Draughts Federation. Available from: https:// www.fmjd.org/.

27. International Federation of Match Poker. Available from: https://matchpokerfed.org/about/.

28. The International Go Federation. Available from: https://www.intergofed.org/.

29. World Bridge Federation. Available from: http://www. worldbridge.org.

30. Code of Sports Ethics. Lisbon: Instituto Português do Desporto e Juventude, I.P.; 2015. Available from: http:// www.pned.pt/media/31485/Code-of-Sports-Ethics. pdf.

31. Anti-Doping Regulations (Medical Commission). Available from: https://www.fide.com/fide/fide-anti-dopingregulations.html.

32. Chess WADA - Anti-Doping Policy, Nutrition and Health. Available from: http://www.fide.com/FIDE/handbook/ WADA\%20Anti\%20Doping.pdf.

33. The IGF Anti-Doping Regulation. Available from: http:// www.intergofed.org/about-the-igf/the-igf-anti-doping-regulation.html.

34. World Anti-Doping Agency. Prohibited list. January 2017. Available from: https://www.wada-ama.org/sites/ default/files/resources/files/2016-09-29_-_wada_ prohibited_list_2017_eng_final.pdf.

35. Master Points Rules. Available from: http://db.worldbridge.org/Repository/departments/mps/rules.asp.

36. XXVI World chess championship among seniors 50+ and 65+. General provisions [in Russian]. Available from: http://www.wscc2016.net/uploads/downloads/wscc2016-ru.pdf.

37. Krasnikov AA. Fundamentals of the theory of sports competitions [in Russian]. Moskva: Fizicheskaya Kultura; 2005.

38. Platonov VM, Bulatova MM. Physical training of athletes [in Ukrainian]. Kyiv: Olimpiiska Literatura; 1995.

39. Dolbysheva N. Autonomy of the system of sports activities in non-Olympic sports [in Ukrainian]. Sportyvnyi Visnyk Prydniprov'ia. 2017;1:22-30.

40. Dolbysheva N. Theoretical and methodological provisions of intellectual training as a basis for the achievement of sports results in mind sports [in Ukrainian]. Fizychna Kultura i Sport: Zbirnyk Naukovykh Prats. 2016;2:139-145.

41. Berezin VH, Tymoshenko LV, Zakharchuk IR. Chess. Curriculum for children's and youth sports schools, specialized children's and youth schools of Olympic reserve, schools of higher sports excellence [in Ukrainian]. Kyiv: Respublikanskyi Naukovo-Metodychnyi Kabinet Ministerstva Ukrainy u Spravakh Sim’i, Molodi ta Sportu; 2008.

42. Nikitin AP, Rodin AA, Yankovskaya TA, Tsaruk GG. The curriculum of continuing education for children 
'Chess' (for youth and youth sports schools) [in Russian]. Krasnodar: Specialized children and youth sports school of the Olympic reserve 'Sputnik'; 2011.

43. Obelets IS. The main program with the advanced education of the science-and-technology direct 'SHASHKI' is the $4^{\text {th }}$ yeaar [in Ukrainian]. Putyvl: District Centre Pozashkilnoï Robot; 2014.

44. Vinnychenko VO, Koval OM, et al. (eds.). Chess. Curriculum for extracurricular institutions, general educational institutions, and palaces of culture and creativity [in Ukrainian]. Kyiv: Sportyvnyi Komitet Ukrainy; 2010.

45. Pityn M. Theoretical training in sports [in Ukrainian]. Lviv: LDUFK; 2015.

46. Kalenov AV. Educational program of additional education for children 'Chess' [in Russian]. Available from: https://refdb.ru/look/2930135-pall.html.

47. Professional training of chess [in Russian]. Available from: http://64ab.ru/interesnye-materialy-oshakhmatakh/182-ocherk-o-shakhmatakh.

48. Shardakov MM. Essays in schoolchildren psychology [in Russian]. Moskva: State Pedagogical Publishing House of the Ministry of Education of the RSFSR; 1955.

49. Stolyarenko LD (ed.). Psychology [in Russian]. SankPeterburg: Piter; 2008.

50. Chehov V, Komplyakov V. The training program for chess players of the first category, candidates for master of sports [in Russian]. Moskva: Mozhayskiy Poligrafkombinat; 2009.

51. Abramov LY. Chess dictionary [in Russian]. Moskva: Fizkultura i Sport; 1964.

52. Lisitsyin GM. Chess strategy and tactics [in Russian], $2^{\text {nd }}$ ed. Moskva: Fizkultura i Sport; 1958.

53. Piaget J. The development of intelligence in children [in French]. Paris: Delachaux et Niestlé; 1936.

54. How to develop intelligence: 10 most effective ways [in Russian]. Available from: https://shard-copywriting. ru/train-brain/.

55. Dolbysheva N. Basics of special-practical training in mind sports [in Ukrainian]. Sportyvnyi Visnyk Prydniprov'ia. 2018;1:22-30.

56. Dolbyisheva NG. Fundamentals of psychological training in mind sports [in Russian]. In: Olympic Sports and Sports for All: Proceedings of the XXII International Congress, October 25-28, 2018, Tbilisi, Georgia [in Russian]; 428-432.

57. Vysochina NL. Psychological support in the system of training athletes in Olympic sports [in Ukrainian]. PhD dissertation in physical education and sports sciences: 24.00.01. Kyiv: Natsionalnyi Universytet Fizychnoho Vykhovannia i Sportu Ukrainy; 2018.

58. Van Zung D. Training and competitive loads in the annual cycle of training chess players [in Russian]. PhD dissertation in pedagogical sciences: 13.00.04. Moskva: Rossiyskiy Gosudarstvennyiy Universitet Fizicheskoy Kulturyi, Sporta i Turizma; 2006.
59. Lupandin V, Surnina O. Subjective scales of an 'active' and 'passive' time. In: Proceedings of the $8^{\text {th }}$ Annual Meeting of the ISR. Stockholm; 1992; 125.

60. Kozlova OV. The influence of various baseline conditions of chess players on sports results [in Russian]. PhD dissertation in pedagogical sciences: 13.00.04. Moskva: Rossiyskaya Gosudarstvennaya Akademiya Fizicheskoy Kulturyi; 2000.

61. Lupandin VI. Subjective scales of space and time [in Russian]. Sverdlovsk: UrGU; 1991.

62. Ozolin NG. Coach's handbook [in Russian]. Moskva: AST Astrel; 2003.

63. On the organization of educational and training work of children and youth sports schools [in Ukrainian]. Nakaz Ministerstva Molodi ta Sportu Ukrainy, 17.01.2015; 67.

64. Nabatnikova MY. The construction process of sports training [in Russian]. In: Nabatnikova MY, Filin VP (ed.), Modern system of sports training [in Russian]. Moskva: SAAM; 1995; 351-389.

65. Dolbysheva NH. Methodical bases of stages of longterm process of sports training in intellectual types [in Ukrainian]. Sportyvnyi Visnyk Prydniprov’ia. 2016; 2:48-55.

66. Dolbysheva N. Systemic factors of training athletes in mind sports [in Ukrainian]. Sportyvnyi Visnyk Prydniprov’ia. 2017;2:59-68. 